\title{
Analisis Drug Related Problem Terkait Dosis pada pasien Balita dengan Diagnosis Diare di Puskesmas Lumpatan Kabupaten Musi Banyuasin Periode Januari-Maret 2018
}

\author{
Eka Afrika ${ }^{1}$, Helni Anggraini ${ }^{2}$, Muhammad Romadhon $^{3}$, Satra Yunola ${ }^{4}$ \\ 1,2Universitas Kader Bangsa Palembang \\ Correspondence email: afrikaeka@yahoo.co.id; helnianggraini589@gmail.com; madhon1989@gmail.com; \\ satrayunola@ymail.com
}

\begin{abstract}
Abstrak. Penyakit diare merupakan penyakit endemis di Indonesia dan juga merupakan penyakit potensial Kejadian Luar Biasa (KLB) yang sering disertai dengan kematian. Puskesmas Lumpatan Kabupaten Musi Banyuasin yang merupakan salah satu puskesmas yang terdapat di daerah kabupaten Musi Banyuasin dimana jumlah sampel dalam penelitian ini sebnyak 20 pasien diantaranya terdapat pasien jenis kelamin laki-laki sebanyak 7 pasien dan pasien perempuan sebanyak 13 pasien. Pasien balita dengan usia Neonatus(0-1 bulan) sebanyak 0 pasien, pada Bayi ( $>1$ bulan-2 tahun) sebanyak 16 pasien sedangkan Anak $(>2$ tahun-5 tahun) sebanyak 6 pasien. Jumlah pasien balita yang mendapatkan pengobatan oralit sebanyak 4 pasien, zink sebanyak 11 pasien dan cotrimoxazole sebanyak 15 pasien, dimana terdapat drug realted problems terkait pada dosis,yang mendapatkan dosis terlalu rendah yaitu obat zink sebesar $9,10 \%$.
\end{abstract}

Kata kunci: Balita; Diare; Cotrimoksazole; Oralit; Puskesmas; dan Zink

Abstract. Diarrheal disease is an endemic disease in Indonesia and is also a potential illness of Extraordinary Occurrence (KLB) which is often accompanied by death. Puskesmas Lumpatan of Musi Banyuasin Regency which is one of the public health centers in Musi Banyuasin district where the number of samples in this study is 20 patients including 7 male patients and 13 female patients. Toodler patients with Neonate age (0-1 months) were 0 patients, in infants (1 month-2 years) as many as 14 patients while children (2 years-5years) were 6. The number of children under-five patients who received oralitic treatment were 4 patients, zinc as many as 11 patients and cotrimoxazole as many as 15 patients, where there are drug-related problems only at the drug delivery that is too low the zinc drug is $9,10 \%$

Keywords: Diarrhea; Puskesmas; Toddler; Oralit; Cotrimoksazole and Zink

\section{PENDAHULUAN}

Penyakit diare merupakan penyakit endemis di Indonesia dan juga merupakan penyakit potensial Kejadian Luar Biasa (KLB) yang sering disertai dengan kematian. Pada tahun 2016 terjadi 3 kali KLB diare yang tersebar di 3 provinsi, 3 kabupaten, dengan jumlah penderita 198 orang dan kematian 6 orang (CFR 3,04\%). Target cakupan pelayanan penderita diare yang datang ke sarana kesehatan dan kader kesehatan adalah $10 \%$ dari perkiraan jumlah penderita diare (insidens diare dikali jumlah penduduk di satu wilayah kerja dalam waktu satu tahun). Insidensi diare nasional hasil Survei Morbiditas Diare tahun 2014 yaitu sebesar 270 per 1.000 penduduk. Maka diperkirakan jumlah penderita diare di fasilitas kesehatan pada tahun 2016 sebanyak 6.897.463 orang, sedangkan jumlah penderita diare yang dilaporkan ditangani di fasilitas kesehatan adalah sebanyak 3.198.411 orang atau 46,4\% dari target (Kemenkes RI, 2016).

Penyebab utama kematian akibat diare adalah tata laksana yang tidak tepat baik dirumah maupun di sarana kesehatan. Target MDG'S ke-4 adalah penurunan kematian anak dari tahun 1990 menjadi 2 per 3 bagian sampai 2015. Salah satu upaya untuk menurunkannya adalah dengan menurunkan kematian karena diare.
Untuk menurunkan kematian karena diare perlu tata laksana yang cepat dan tepat. Karena setiap tahun lebih kurang lima juta anak-anak dibawah usia lima tahun meninggal dunia akibat penyakit diare, $65 \%$ diantaranya karena mengalami dehidrasi (Kemenkes RI,2011).

Drug Related Problem merupakan bagian dari medication error yang dihadapi hampir semua negara di dunia. Pada tahun 1997 di Amerika Serikat (AS) tercatat 160.000 kematian dan 1 juta pasien dirawat di rumah sakit akibat kejadian obat yang diresepkan. Morse mengestimasikan bahwa di AS, biaya penyakit terkait obat yang diresepkan adalah 7 milyar dolar setiap tahun (Strand, et al., 1990 dalam Nabila, 2016). Drug Related Problem pada anak yang pernah dipublikasikan adalah Drug Related Problem dalam pengobatan Dengue Hemoraggic Fever (DHF) pada pasien pediatri. Dari 65 pasien pediatri dengan diagnosis DHF, terdapat Drug Related Problem kategori obat tanpa indikasi sebanyak 22 pasien, dosis obat kurang sebanyak 14 pasien, dosis obat lebih sebanyak 10 pasien, obat salah sebanyak 4 pasien, dan indikasi tanpa obat sebanyak 2 pasien (Yasin, ddk., 2009).

Penelitian yang dilakukan oleh Nabila (2016) menunjukan bahwa penyakit penyerta yang sering dialami pasien adalah Kejang Demam Kompleks (KDK) 
Eka Afrika et al, Analisis Drug Related Problem Terkait Dosis pada pasien Balita dengan Diagnosis Diare di Puskesmas Lumpatan Kabupaten Musi Banyuasin Periode Januari-Maret 2018

(47,05\%) dengan kejadian Drug Related Problem terbanyak ialah interaksi obat $(31,18 \%)$, diikuti dosis obat melebihi dosis terapi $(30,10 \%)$, dosis obat kurang dari dosis terapi $(18,27 \%)$, obat tanpa indikasi $(9,67 \%)$, indikasi tanpa obat $(8,60 \%)$ dan ketidaktepatan pemilihan obat $(2,15 \%)$, jumlah penyakit penyerta berpengaruh terhadap jumlah Drug Related Problem $(\mathrm{P}=0,028)$, jumlah penggunaan obat tidak berpengaruh secara bermakna terhadap jumlah Drug Related Problem $(\mathrm{P}=0,100)$. Hasil penelitian yang dilakukan oleh Asyhari (2017) menunjukkan bahwa pasien anak yang menderita diare adalah sebanyak 73 pasien yang didominasi oleh anak yang berjenis kelamin laki-laki sebanyak 42 pasien (57,53\%) dengan mayoritas pasien usia 0-1 tahun sebanyak 48 pasien $(65,75 \%)$. Jenis Drug Related Problems yang paling banyak terjadi adalah ketidaktepatan pemilihan obat antibiotika sebesar 20 kasus $(27,40 \%)$, diikuti indikasi tanpa obat sebesar 26,03\%, dan obat tanpa tanpa indikasi sebesar 10,96\%.

Puskesmas Lumpatan Kabupaten Musi Banyuasin yang merupakan salah satu puskesmas yang terdapat di daerah kabupaten Musi Banyuasin, dimana puskesmas Lumpatan Kabupaten Musi Banyuasin memiliki beberapa poli pelayanan yaitu poli anak, poli umum, poli lansia, poli kebidanan atau KIA, poli gizi, poli imunisasi, poli gigi, poli TB paru, laboratorium, sterilisasi, pelayanan apotik serta ruang rekam medik atau ruang pendaftaran. Puskesmas Lumpatan memiliki 2 tenaga kerja dokter umum dan 1 tenaga kerja apoteker. Pada umumnya pasien balita wilayah kerja puskesmas Lumpatan diberikan obat dalam bentuk sediaan puyer atau racikan serta dalam bentuk cairan.

\section{METODE}

Penelitian ini merupakan jenis penelitian observasional deskriptif dengan rancangan cross sectional. Pengambilan data secara retrospektif melalui data sekunder, yaitu berupa ruang rekam medik di puskesmas Lumpatan.

\section{HASIL DAN PEMBAHASAN}

Berdasarkan dari hasil penelitian yang dilakukan oleh peneliti dapat dilihat bahwa pengobatan pada pasien balita yang menderita penyakit diare di Puskesmas Lumpatan Kecamatan Sekayu sebagai berikut:
Tabel 1. Karakteristik Usia Pasien Balita dengan Diagnosis Diare pada Periode Januari sampai Maret 2018 di Puskesmas Lumpatan Kabupaten Musi Banyuasin

\begin{tabular}{lccr}
\hline No & Usia & Jumlah Pasien & Persentase \\
\hline 1 & Neonatus (0-1bulan) & 0 & $0 \%$ \\
2 & Bayi (>1bln-2 tahun) & 14 & $70 \%$ \\
3 & Anak (>2thn-5 tahun) & 6 & $30 \%$ \\
& Total & 20 & $100 \%$ \\
\hline
\end{tabular}

Berdasarkan hasil Tabel di atas dapat diketahui bahwa jumlah persentasi pasien balita yang menderita penyakit diare paling banyak pada usia bayi ( $>1$ buian-2 tahun) sebesar 70\% pasien sedangkan pada usia anak(>2 tahun-5 tahun)pasien balita yang menderita penyakit diare sebanyak $30 \%$.

Tabel 2. Karakteristik Jenis Kelamin Pasien Balita dengan Diagnosis Diare pada Periode Januari sampai Maret 2018 di Puskesmas Lumpatan Kabupaten Musi Banyuasin

\begin{tabular}{cccc}
\hline No. & Jenis Kelamin & Jumlah Pasien & Persentase \\
\hline 1. & Perempuan & 13 & $60 \%$ \\
2. & Laki-laki & 7 & $40 \%$ \\
& Total & 20 & $100 \%$ \\
\hline
\end{tabular}

Berdasarkan hasil Tabel di atas dapat diketahui bahwa jumlah persentasi pasien balita yang menderita penyakit diare paling banyak yaitu pasien jenis kelamin perempuan sebesar $60 \%$ pasien sedangkan jenis kelamin laki-laki sebanyak $40 \%$. .

Tabel 3. Persentase Penggunaan Obat Pada Pasien Balita dengan Diagnosis Diare Periode Januari sampai Maret 2018 di Puskesmas Lumpatan Kabupaten Musi Banyuasin

\begin{tabular}{clcc}
\hline No. & \multicolumn{1}{c}{ Nama Obat } & $\begin{array}{c}\text { Jumlah } \\
\text { Pasien }\end{array}$ & Persentase \\
\hline 1. & Cotrimoxazole & 9 & $45 \%$ \\
2. & Cotrimoxazole + Zink & 5 & $25 \%$ \\
3. & Cotrimoxazole + Zink + Oralit & 1 & $5 \%$ \\
4. & Zink & 2 & $10 \%$ \\
5. & Zink + Oralit & 3 & $15 \%$ \\
\hline
\end{tabular}

Berdasarkan tabel di atas pasien balita yang menggunakan obat cotrimoxazole sebesar 45\%, Cotrimoxazole + Zink sebesar $25 \%$, Cotrimoxazole + Zink + Oralit sebesar 5\%, Zink sebesar 10\% serrta Zink + Oralit sebesar $15 \%$.

Tabel 4. Hasil Persentase Pengamatan Drug Related Problem terkait dosis pada pasien balita dengan diagnose diare di Puskesmas Lumpatan

\begin{tabular}{lcccccc}
\hline \multirow{2}{*}{ Drug Related Problems } & \multicolumn{2}{c}{ Obat Diare } & \multicolumn{2}{c}{ Ket. } \\
\cline { 2 - 7 } & \multicolumn{2}{c}{ Cotrimoxazole } & \multicolumn{2}{c}{ Zink } & \multicolumn{2}{c}{ Oralit } \\
\cline { 2 - 7 } & $\mathrm{n}$ & $\%$ & $\mathrm{n}$ & $\%$ & $\mathrm{n}$ & $0 \%$ \\
\hline Dosis Terlalu Rendah & 0 & $0 \%$ & 1 & $9,10 \%$ & 0 & $0 \%$ \\
Dosis Terlalu Tingg & 0 & $0 \%$ & 0 & $0 \%$ & 0 & $0 \%$ \\
Frekuensi Terlalu Singkat & 0 & $0 \%$ & 0 & $0 \%$ & 0 & $0 \%$ \\
Frekuensi Terlalu Lama & 0 & $0 \%$ & 0 & $0 \%$ & 0 & 0 \\
\hline
\end{tabular}

Keterangan:

n : Jumlah Pasien 
Eka Afrika et al, Analisis Drug Related Problem Terkait Dosis pada pasien Balita dengan Diagnosis Diare di Puskesmas Lumpatan Kabupaten Musi Banyuasin Periode Januari-Maret 2018

$\% \quad$ : Persentase

Berdasarkan tabel diatas semua pasien balita yang mendapatkan resep antibiotik cotrimoxazole menunjukkan bahwa semua pasien balita tidak mendapatkan dosis terlalu rendah dan tidak terlalu tinggi serta untuk frekuensi pemberian obat seluruh pasien balita mendapatkan frekuensi penggunaan obat selama 3 hari, disebabkan terapi yang digunakan secara empiris yaitu penggunaan antibiotik pada kasus infeksi yang belum diketahui jenis bakteri penyebabnya (Permenkes RI, 2011).

Berdasarkan tabel diatas untuk obat zink didapatakan bahwa pasien balita yang mendapatkan terapi obat terlalu rendah sebanyak $9,10 \%$ sedangkan untuk frekuensi pemberian obat seluruh pasien balita mendapatkan frekuensi penggunaan obat dalam jangka waktu normal yaitu selama 10 hari penggunaan. Meskipun diare pada balita sudah berhenti diarenya karena sudah terbukti membantu memperbaiki mukosa usus yang rusak saat balita diare dan meningkatkan kekebalan tubuh secara kekebalan tubuh secara keseluruhan (Kemenkes, 2015).

Berdasarkan tabel diatas maka didapatakan bahwa semua pasien balita yang diresep oralit tidak mendapatkan dosis terlalu rendah dan dosis yang terlalu tinggi sedangkan untuk frekuensi pemberian obat seluruh pasien balita diberikan obat oralit sebanyak 3 sachat diberikan sampai diare pada balita sudah berhenti (Kemenkes, 2015).

\section{Pembahasan}

Puskesmas Lumpatan merupakan salah satu puskesmas yang berada di wilayah kecamatan sekayu yang bekerja dibawah wewenang dinas kabupaten Musi Banyuasin yang memiliki peranan penting dalam meningkatkan kesehatan masyarakat yang tinggal di wilayah kerja Puskesmas Lumpatan dalam hal ini sejalan dengan tugas dan fungsi Puskesmas Lumpatan. Penelitian ini dilakukan secara retrospektif melalui data sekunder, yaitu berupa ruang rekam medik dan ruang pelayanan apotik di puskesmas Lumpatan.

Populasi dalam penelitian ini merupakan seluruh data pasien balita penyakit diare rawat jalan di wilayah kerja Puskesmas Lumpatan Kabupaten Musi Banyuasin pada periode Januari sampai dengan Maret 2018 yaitu sebanyak 22 pasien. Berdasarkan rumus pehitungan sampel yang di dapat adalah sebesar 20 sampel pasien balita yang menderita penyakit diare.

Pengumpulan data yang diambil merupakan data skunder yaitu nama pasien, berat badan pasien, usia pasien, jenis kelamin, diagnose, obat yang digunakan, dosis, frekuensi penggunaan, serta durasi obat yang diberikan petugas ke pada pasien balita penderita nyakit diare.

Berdasarkan hasil dari penelitian ini didapatkan bahwa jumah pasien balita yang menderita penyakit diare jenis kelamin laki-laki sebanyak 7 pasien dan perempuan sebanyak 13 pasien dan untuk karakteristik usia pasien Neonatus(0-1bulan) sebanyak 0 orang, pada Bayi (>1 bulan-2 tahun) sebanyak 14 orang sedangkan pada Anak(>2 tahun-5 tahun) sebanyak 6 orang. Sedangkan untuk pasien balita yang menggunakan obat cotrimoxazole sebanyak 15 pasien, zink sebanyak 11 pasien dan oralit sebanyak 4 pasien yang diberikan oleh petugas.

Pada pasien yang menderita diare, dehidrasi merupakan gejala yang paling sering dijumpai. Dehidrasi memicu gangguan kesehatan mulai dari gangguan ringan seperti mudah mengantuk hingga penyakit berat seperti penurunan fungsi ginjal. Pada awalnya anak akan merasa haus karena telah terjadi dehidrasi, bila tidak ditolong dehidrasi akan bertambah berat dan timbul gejala-gejala diare yang semakin buruk bahkan bila berkelanjutan lebih lama maka dapat mengakibatkan kejadian yang tidak inginkan terjadi. Oleh karena itu pengobatan awal untuk mencegah dan mengatasi keadaan dehidrasi sangat penting pada anak dengan diare. Pemberian cairan yang tepat dengan jumlah yang memadai merupakan modal yang utama untuk mencegah dehidrasi. Cairan harus diberikan sedikit demi sedikit dengan frekuensi sesering mungkin untuk mencengah terjadinya dehidrasi yang berkelanjutan, cairan yang dapat digunakan untuk pertolongan awal yaitu cairan oralit yang mengandung $\mathrm{NaCl} 2.6 \mathrm{~g}$, Na Citrate $2.9 \mathrm{~g}, \mathrm{KCl} 1.5 \mathrm{~g}$, Glucose $13.5 \mathrm{~g}$, $\mathrm{Na}+75 \mathrm{mEq} / \mathrm{l}, \mathrm{K}+20 \mathrm{mEq} / \mathrm{l}$, Citrate $10 \mathrm{mmol} / \mathrm{l}, \mathrm{Cl}-65$ $\mathrm{mEq} / \mathrm{l}$ dan Glucose $75 \mathrm{mmol} / \mathrm{lyang}$ dapat membantu menghentikan terjadinya dehidrasi (Kemenkes, 2011). Hasil dari lampiran 3 menunjukan bahwa pasie balita yang mendapatkan obat oralit sebanyak 4 pasien balita. Berdasarkan lampiran 7 menunjukkan bahwa semua pasien balita tidak mendapatkan dosis terlalu rendah dan dosis yang terlalu tinggi sedangkan untuk frekuensi pemberian obat seluruh pasien balita mendapatkan frekuensi penggunaan diberikan sampai diare pada balita sudah berhenti (Kemenkes, 2015).

Pengobatan selanjutnya dengan pemberian terapi zinc, setelah penderita diare diketahui derajat dehidrasinya maka pasien diberi tablet zinc yang berguna untuk menguramhi lama dan tingkat keparahan diare, mengurangi volume air besar, mengurangi volume tinja dan menurunkan kekambuhan diare pada tiga bulan berikutnya (Fontaine, 2008). Berdasarkan penelitian yang dilakukan di puskesmas lumpatan didapatkan bahwa jumlah pasien balita yang mendapatkan obat zink sebanyak 11 pasien. Berdasarkan lampiran 6 menunjukkan bahwa semua pasien balita tidak mendapatkan dosis terlalu rendah sebanyak 9,10\% sedangkan untuk frekuensi pemberian obat seluruh pasien balita mendapatkan frekuensi penggunaan obat dalam jangka waktu normal yaitu selama 10 hari penggunaan meskipun diare pada balita sudah berhenti diarenya karena sudah terbukti membantu memperbaiki mukosa usus yang rusak saat balita diare dan 
meningkatkan kekebalan tubuh secara kekebalan tubuh secara keseluruhan (Kemenkes, 2015). Berdasarkan data lampiran 3 menunjukkan bahwa hamper semua pasien diberikan obat antibiotik cotrimoxazole sebanyak 15 pasien.

Berdasarkan hasil di atas menunjukkan bahwa semua pasien balita tidak mendapatkan dosis terlalu rendah dan untuk dosis yang terlalu tinggi sedangkan untuk frekuensi pemberian obat seluruh pasien balita mendapatkan frekuensi penggunaan obat dalam jangka waktu normal yaitu selama 3 hari, disebabkan terapi yang digunakan secara empiris yaitu penggunaan antibiotik pada kasus infeksi yang belum diketahui jenis bakteri penyebabnya (Permenkes RI, 2011).

\section{SIMPULAN}

Berdasarkan hasil penelitian dan pembahasan tentang ketersediaan dan kerasionalan penggunaan antibiotik pada pasien balita penderita penyakit diare adalah sebagai berikut:

1. Jumlah pasien balita yang menderita penyakit diare jenis kelamin laki-laki sebanyak 7 pasien dan perempuan sebanyak 13 pasien

2. Karakteristik usia pasien Neonatus(0-1 bulan) sebanyak $0 \%$ pasien, pada Bayi(>1 bulan- 2 tahun) sebanyak $70 \%$ pasien sedangkan pada Anak $(>2$ tahun-5 tahun) sebanyak 30\%.

3. Berdasarkan penelitian menunjukkan bahwa pasien balita yang mendapatkan obat oralit sebanyak 4 pasien dan dosis yang diberikan sesuai dengan dosisi literatur sedangkan untuk frekuensi pemberian obat seluruh pasien balita mendapatkan frekuensi penggunaan obat dalam jangka waktu normal yaitu selama 3 hari penggunaan hingga diare pada balita berhenti.

4. Berdasarkan penelitian menunjukkan bahwa pasien balita yang mendapatkan obat zink sebanyak 11 pasien dan dosis yang diberikan tidak terlalu rendah sebesar 9,10\% Serta untuk frekuensi pemberian obat seluruh pasien balita mendapatkan frekuensi penggunaan obat dalam jangka waktu normal yaitu selama 10 hari penggunaan.

5. Berdasarkan penelitian menunjukkan bahwa hampir semua pasien diberikan obat antibiotik cotrimoxazole sebanyak 15 pasien dan dosis yang diberikan tidak terlalu rendah dan dosis yang terlalu tinggi serta untuk frekuensi pemberian obat seluruh pasien balita mendapatkan frekuensi penggunaan obat dalam jangka waktu normal yaitu selama 3 hari penggunaan dikarenakan menggunakan prinsip penggunaan antibiotik secara empiri (belom diketahu bakteri penyebabnya).
DAFTAR PUSTAKA

Asyhari, Asyikin. 2017. Studi identifikasi drug releated problem's (drps) pada pasien diare di perawatan anak RSUD pangkep sulawesi. Media farmasi vol. Xiii. No. 2. 14-22 november 2017

Depkes RI. 2011. Buku Saku Petugas Kesehatan. Jakarta: Departemen Kesehatan Republik Indonesia Direktorat enderal Pengendalian Penyakit dan Penyehatan Lingkungan.

Fontaine, O. 2008. Bukti Keamanan dan Suplementasi Zinc pada Penanganan

Kementerian Kesehatan RI. 2011. Panduan Sosialisasi Tatalaksana Diare Balita. Kementerian Kesehatan RI Direktorat Jenderal Pengendaalian Penykit dan Penyehatan Lingkungan, Jakarta.

Kementerian Kesehatan RI. 2015. Petununjuk Teknis Layanan Rehidrasi Oral Akif. Kementerian Kesehatan RI Direktorat Jenderal Pengendaalian Penykit dan Penyehatan Lingkungan, Jakarta.

Kementrian Kesehatan Ri. 2016. Profil Kesehatan Indonesia 2015. Jakarta: Kementrian Kesehatan $\mathrm{Ri}$,

Nabilah, UW. 2016. Identifikasi drug related problems (drps) diare akut infeksi pada pasien pediatri di instalasi rawat inap $r s$ " $x$ " di kota tangerang selatan periode januari-desember 2015. Jakarta: Universitas Islam Negeri Syarif Hidayatullah

Yasin, N.M., Sunowo, J., Supriyadi, E.. 2009. Drug Related Problem (DRP) Of Dengue Hemorragic Fever (DHF) Medication In Pediatric Patient. Majalah Farmasi Indonesia. 20(1), 27 - 34, 2009 